\title{
Digitalisation of Electoral Process and Its Impact on the Voting Behaviour of People in India
}

\author{
Jayasree Nath
}

\begin{abstract}
Digitalisation is a process to improve human common errors in developmental process. It covers all aspects from science and technology to communication, social, political, economic areas. Digitalisation makes life easier. India being a globalised, democratic country introduced digitalisation process to improve the conditions of people living in India. The present Prime Minister himself advocated 'digital India' campaign to reduce corruption, fast transaction and remove the manual obstacles for a faster economic growth and development of India. Digitalisation of electoral process means the use of digital equipments in the election system in India. It includes technique, tools used in the campaign process, introduction of Electoral Voting Machines (EVMs) for result declaration etc. This paper will examine the digitalisation of electoral process in India with special reference to the impact of digitalisation on voting behaviour of people in the last two general elections. Secondly, the changes it has created in 2014 and 2019 general elections compare to the earlier election and followed by data analysis part of the paper and conclusion. In conclusion the paper tried to explain the pros and cons of digitalisation of the election process and its impact on the voting behaviour of people.
\end{abstract}

Keywords: Digitalisation, Election, social media, India, Platforms.

\section{INTRODUCTION}

Post-economic liberation of Indian economy, India has witnessed economic growth and development in terms of GDP (Gross Domestic Product) growth and purchasing power parity. India ranked third position after U.S while China holds top position. This led significant changes and development across all sectors. IT (Information Technology) sector is one of such sector that has seen unprecedented growth and development. This development and growth of IT industry has positively helped in the process of digitalisation of India. The current Prime Minister, Narendra Modi has started a 'Digital India' programme spending over Rs 3,073 crore aiming to build smart cities along with connecting rural areas of India with high speed internet networks that lead to improve digital literacy accelerating the pace of digitalization process in the country (Kurup, 2018). It ensures to minimize the red tapism in public services by improving online infrastructure and internet connectivity or by providing easily available electronic data to the general public.

Revised Manuscript Received on October 30, 2019.

* Correspondence Author

Dr. Jayasree Nath*, Assistant Professor, NEF College, Guwahati, India.

(C) The Authors. Published by Blue Eyes Intelligence Engineering and Sciences Publication (BEIESP). This is an open access article under the CC-BY-NC-ND license http://creativecommons.org/licenses/by-nc-nd/4.0/
The Digital India programme has touched nearly all aspect of people's live ranging from social communication via social media platform, work, travel, healthcare, education, shopping, entertainment etc. It has reduced the gap between rural and urban areas by digitalizing the rural areas too. Any kind of information shared in digital platform reach both urban and rural areas at the same time. It has narrowed down the communication gap between people living in rural and urban areas.

\section{METHODOLOGY}

The study is primarily qualitative in nature based on secondary sources. The study tries to understand the changing nature of communication between the people after technological and electronic revolution in India with special reference to the electoral process. The study attempts to explain particularly the last two general elections. The study tries to understand strategic role played by digital platforms and tactics used by political parties to interact with the voters. It finds out that digital platforms such as facebook, whatsapp, twitter have found a new place in the political process in India. Moreover, it found that social media played a vital and historic role in process of popularising political slogans of parties and created a paradigm shift in the voting behaviour of people in the two general elections where major political issues have been raised and contested.

\section{PURPOSE OF THE STUDY}

The purpose of the study is to understand the dynamics in electoral process of India. It tries to explain the changes created by digitalisation of election campaign specially and its impact on the voting behaviour of people in India. India although have been using digital equipments in the election process since long time, the last two general election added a new dimension in the election behaviour of people due to the extensive use of digital platforms in the election process specially in terms of canvassing for elections by political leaders and parties. It changed the relation between voter and representative by narrowing down the communication gap between the two. The study shows both positive and negative impact digitalisation has done on the voting behaviour of people. However, awareness, digital literacy, strict vigilance including implementing strict laws for spreading hatred during election or afterwards via social media can better the process of political mobilisation on the concerned issues among masses in future. 


\section{Digitalisation of Electoral Process and Its Impact on the Voting Behaviour of People in India}

\section{FINDINGS AND RESULTS}

In developed countries, electoral platforms play a significant role in terms of election campaigning since many years. India since 2009 has witnessed the growing practices of electronic platforms in the election campaigning process of India.

Although, there was confusion and contrast perspective among the researchers in terms of the role of digital platforms has been playing popularising leaders and political parties. However, the result of 2014 and 2019 general elections created a massive change in terms of digitalisation of election process in India especially canvassing and popularising political slogans of political parties. The popular slogan 'Acche Din (good days)', 'Parivartan (Change)' promoted by BJP (Bharatiya Janata Party) has gained momentum support from the people of all over the country. This study proved the hypothesis of digital platform playing a significant role in the voting behaviour of people in India. The study comparatively tries to explain the increase penetration of social media in the people's life in India and the change digital platforms has created in the election results of 2014 and 2019.

\section{A. Digitalisation of Electoral process and its impact on the voting behaviour of people:}

Digitalisation of Electoral process means the introduction and use of digital and electronic technique, methods and tools in the election process. It includes both the use of digital technique to bring efficiency in the election process and use of digital platform like social media, electronic media and other digital communication such as mobile in the campaigning process or sharing information, reports via the use of electronic equipments etc. Online Databases facilitate smooth functioning, accurate result and advanced electoral rolls. It helps to prevent fraud and multiple voting. Accurate voter registration can help to promote one person one vote system leading equality among voters. Additionally, the illiterate rural voters those who lack knowledge to read and write would get opportunity to include their casting vote for their choice candidate as EVM (Electronic Voting Machine) allows one choice vote. In India, 31\% of adults are illiterate resulting a large numbers of ballots were previously discarded due to improper marking on the ballot papers. The introduction of EVMs has eliminated this problem. It is also useful against the malpractices earlier practised by political parties in the polling centre to favour their candidates. Digitalisation also enables faster vote counting and accurate declaration of result in very short period of time (Russell, Martin and Zamfir 2018).

India, since 1998 general election has been using EVMs all over the country. The EVMs were first used in 1998 in the State Assembly Election in Kerala. Despite the fact that political parties have been using electronic media for every election campaigns to send their messages to reach voters, the last two general elections of India has brought a drastic and magical change in terms of people's participation and use of social, electronic media as platform for campaigning for the elections by political parties. Traditionally, political parties were relied on candidates and their local leaders to make aware about their election manifesto and accordingly cultivated knowledge. They primarily used techniques and methods to know the voters mind and outcome by using technique such as opinion polls, door to door campaigning, respective vote banks, caste, religion profiling, community leaders, volunteers etc. Traditional method practices include booth-wise profiling of voters on the basis of caste, religion and targeting community leaders and religious leaders to pleased the follower. It was more focused on local issues such as ethnicity, identity, areas (rural/urban) etc. and incentives were provided in form of liquor, cash etc (Jigeesh, 2019).

In the last two general elections although traditional process played earlier role, the digital campaigning played a decisive role in terms of political mobilisation. The campaigning was made easier by sending information to people in the way the campaigns were designed, structured, targeted, implemented, and communicated. The introduction of technology and data analysis plays a key role understanding the demographic, religious, caste complexities in a particular region. It helps political parties to understand variables that would play significant role in the election. Contrastly, in a democratic country like India where Citizens enjoy freedom of speech and expressions, digital platform became a viable option for debate, discussion concerning issues that impacted people's life. A well-informed electorate is utmost important factor for successful of democracy as Thomas Jefferson argued and digital platforms such as electronic media, social media are providing information to the people about issues that are affecting their life without any hindrances. It can act like a watchdog against abuses of power by political parties and their leaders. During the time of election campaigns electronic or social media in the last two general elections in India played decisive role by providing information, analysing programme about political parties, policies, candidates and their performance. Twitter, Facebook, Whatsapp, Youtube were being extensively used by candidates, political parties and their campaign managers to woo people of India. The young Indian and first time voters played an important role in these two elections. This also connects with the increase in the numbers of social media users and its impact on the voting pattern led result of the elections of India (Sharma, 2014).

Since 2004 general election, India witnessed a new trend of election campaigning through the uses of electronic platforms especially after the increase of handy mobile phones with internet facilities. Digitalisation has changed the traditional way of method candidate used to apply for election campaign. The hi-tech political canvassing started gaining significance to mobilise people on political and social issues. However, it was not as successful as in the last two general elections. Pre-2014 elections in India there were very limited people using social media platforms concentrating only in urban areas among young generations. However, after 2009 general election, digital platforms started taking a pivotal role in terms of enhancing social communications among the people. This has increased popularity and users of social media platform by youngsters to raise their voice on political, social and economic issues. It has also provided opportunity to the political parties to keep a direct communication with the voters round the clock and read the mind of voters and their expectation. Contrastly, it has provided opportunities for the people to raise their grievances to political parties (Jigeesh, 2019). 
Post-2014 general election, voters were profiled on the basis of age and caste group and targeted them through voice messages of political leaders. Use of social media platforms got top priorities as a medium to reach the voters. The young and first time voters were targeted through the use of social media platforms.

It applied micro-managing of polling booth with collection of real-time voting

data

(https://www.businessinsider.in/general-election-2019-whats app-has-greater-impact-than-all-other-media/articleshow/688 19440.cms). It has allowed political parties and politicians to connect directly with the people across the country reducing travel time and cost. It also provided greater reach to connect with voter than traditional method of communication.

\section{DIGITALISATION OF GENERAL ELECTION: 2014 AND 2019: A BRIEF DISCUSSION}

In developed countries, internet has been playing important role in the election process since long time. In India the last two general elections, a paradigm shift occurred in terms of canvassing in the election campaign by the political parties and leaders. It contributed popularising the slogans used by political parties. In 2014 general election Modi's unique digital events like 'Chai pe Charcha' created unprecedented result that would connect people both at villages and cities. The 2014 general election was largest on record with over 800 million citizens eligible to vote spreading over nine phases. It was the second most expensive campaign after US presidential campaign in the world history (Pathak and Patra, 2015). Evolution in the process of innovative campaigning through the use of social media, digital rallies, crowd fundraising have played effective role in election process and result rather than traditional conventional methods. The result of 2014 general election made a historical change in the election of India declaring NDA as victorious while the incumbent UPA saw the most pronounced defeat. Congress was the centre-left party dominated Indian politics since independence. The Bharatiya Janata Party known for its right-wing Hindu nationalist ideology captured power under the leadership of Prime Minister Narendra Modi in an unprecedented

way (https://ourdataourselves.tacticaltech.org/posts/overview-ind ia/). The 2019 election was more intensive and awarding for BJP compare to 2014 election as BJP was able to regain power winning more seats and got single majority which was very contrast since a decade in the Indian politics. Since mid-70s, a coalition of parties started emerging to form government in India. As a result BJP lead NDA and Congress lead UPA are the major alliance contesting against each other in the election of India. 2014 was also an alliance of parties both working at state and national level contesting elections both state assembly and general election. In this change of the nature of voting behaviour of Indian voters, digital platforms played a major role to create awareness regarding political activities in India, especially among young voters. The popularity of Modi and strategies carried by BJP while electronic media played a decisive role created a major change in the campaigning and popularising the political messages among the masses. Narendra Modi, the Prime Minister himself advocated use of social media to make connection with the people. He has 47.8 million followers on Twitter, 22.9 million followers in Instagram. He used to inform people regarding his policy decisions on important issues in twitter and he used Instagram to send information on his travel plans or sending congratulatory messages to cricket teams etc. (The Economic Times, June 09, 2019). In his election campaign, Modi included strategy covering digital technology, online platforms and data analysis. One of his important component dedicated to a team exclusively look after the digital platforms analysing social media data. It used techniques such as hologram technology to organise rallies and to reach individual voters by providing followers and potential supporters access Modi's speeches on specific issues by simply calling a phone number through the speech recognition start-up Voxsta which is commonly known as 'Political Siri'. In 2019 election, popular slogan used by Congress to counter BJP was 'Chowkidar chor hai' while BJP in return counter Congress with 'Main bhi Chowkidar'. This became viral among the users of social media platforms by adding 'Main bhi Chowkidar' in their name, first by political leaders and followed by followers. Even, the NYAY scheme introduced as promising agenda by only create a little space in digital platforms in the 2019 general election. According to the report published by CSDS (Centre for the Study of Developing Societies) and Konrad Adenauer Stiftung, BJP was far more ahead compare to other parties in terms of using the electronic social media platform influencing the people in the general election of 2019 (CSDS Report on Social Media and Political Behaviour, 2019).

The digital political campaigns are more based on agendas. The digital wings of political parties are engaged in spreading the popular slogans of particular issue they are interested to spread. They carefully designed their agendas to attack opposition parties by dividing people and diverting voters from being unite over an issue that may cause a problem for them. They used the social media platform to defend the policies of their own and criticised the other. They restrain people to know about the reality. However, digital platforms provided a communication platform to users to collect and disseminate information of their choice. It is empowering people to freely articulate, share experiences and raise concerns creating possibility of change (K. Rahul 2016).

The 'Digital India' campaign launched by NDA government has reduced the rural-urban dividend and has hugely impacted in the 2019 general election. While in 2012, according to a report of the Internet and Mobile Association of India found about only 11 percent of total population of India those who used internet is very insignificant in terms of vote count. The rural users were also very limited, out of 137 million only 38 million were based in rural areas. The 'Digital India' campaign made a huge impact on the voters turn out (K. Rahul 2016). The digital India program aims to provide digital infrastructure via extensive broadband and mobile network enabling electric delivery of government services to the citizens. The expansion of internet facilities 3G, 4G to rural areas along with the increase of smartphone users in India compare to 2014 brought another changes in 2019 election which was heavily dependent on the digital platforms. 


\section{Digitalisation of Electoral Process and Its Impact on the Voting Behaviour of People in India}

In terms of campaigning through the digital platforms in the election, Bharatiya Janata Party (BJP), one of the leading nationalist party was far more ahead than Congress, the earlier dominant party in Indian politics since independence.

This party was successful capturing the young generations compared to 2014. Survey by news agency and digital marketing company found that nearly one third of the first time voters were influenced by political messages on social media platforms in 2019 general election (https://economictimes.indiatimes.com/news/elections/lok-sa bha/india/social-media-plays-key-role-in-influencing-first-ti me-voters-report/printarticle/69295605.cms).

\section{A. Data Analysis of 2014 and 2019:}

With increasing popularity, affordability and accessibility the use of digital media platforms among voters have been increasing. Use of Facebook, WhatsApp, Twitter, Youtube, etc. has been increasing among voters (Table 1), whereas, use of newspaper readership and TV news viewership has been in decreasing trend (Table 2).

Table 1: Social media users by voters, 2014-2019

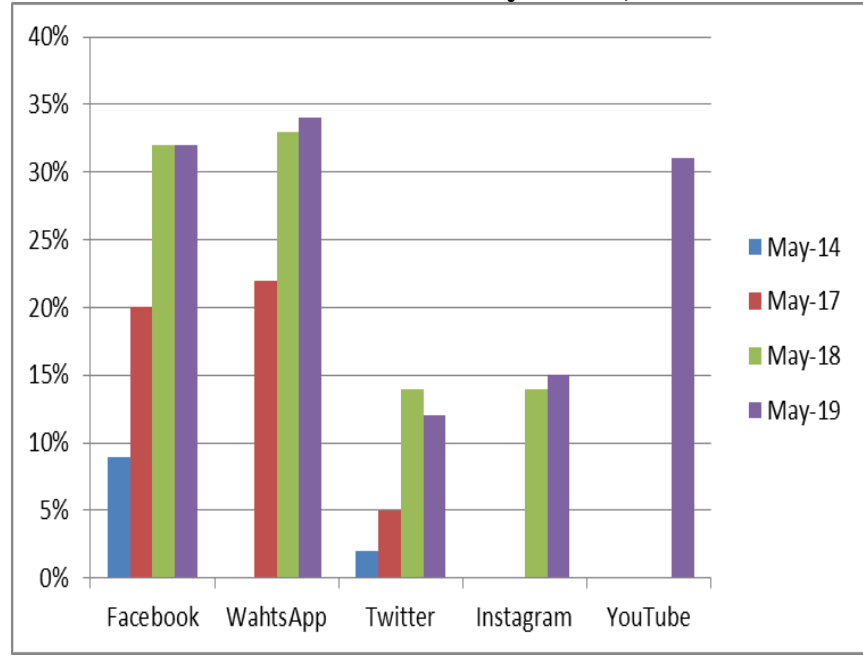

Source: CSDS: report on Social Media \& Political Behaviour

Table 2: TV, newspaper and radio users by voters, 2014-2019

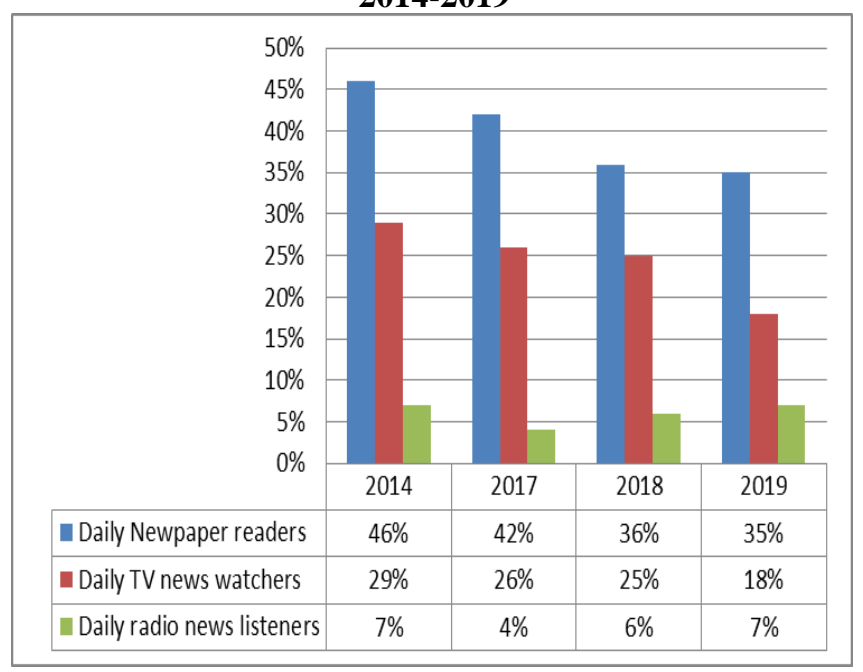

Source: CSDS: report on Social Media \& Political Behaviour

\section{CONCLUSION}

Digital platforms have played an influential role in changing voting behaviour of people in India. Indian society has been moving towards a digital way of life and this has impacted particularly in the last two general elections in an unprecedented way. In last two general elections a record was witnessed in terms of increasing people's participation in the election process. People started using digital platforms such as facebook, whatsapp, youtube to follow their respective political parties and leaders. Some used to create awareness on political issues connected with other social, economic or development related activities. It started working as mirror of a nation and provided voters information to cross check the promises made by political leaders and parties. It worked as a pressure group and further increased active participation of people in the election process and afterwards. These platforms allow people to judge leaders and political parties. It helped people to make decision before they go to cast their vote. On the other hand, political parties and their leaders used digital platforms to popularise their agendas, promises and policies. However, these are substantial limitations in the use of digitalisation of electoral process in India. It includes the dividend among the voters, one group consist of young educated first time voters versus the digital illiterate voters, fake news, false data and promises used by political parties to woo voters etc. Introduction of digital tools and techniques although minimised human errors in election process, but there are a lot of controversy and confusion on the pros and cons of digital platforms that has been playing a significant role mobilising, influencing in the voting behaviour of people in India.

\section{REFERENCES}

1. Kurup, Rajesh (2018), "Government doubles Digit India all allocation to Rs. 3,073 crore; telecom sector disappointed", The Hindu Business Line. Retrieved from https://www.thehindubusinessline.com/economy/budget/govt-doublesdigital-india-allocation-to-3073-crore-telecom-sector-disappointed/arti cle22620283.ece.

2. Russell, Martin and Lonel Zamfir (2018)," Digital Technology in Elections: Efficiency versus credibility?" European Parliamentary Research Service.

3. Jigeesh, AM (2019), 'Why old-world political campaigning a dying art', The Hindu. Retrieved from

https://www.thehindubusinessline.com/news/why-old-world-political-c ampaigning-is-a-dying-art/article26105485.ece.

4. Sharma, Rajeev (2014), New Election tools in New Age India, Ministry of External Affairs, New Delhi. Retrieved from https://mea.gov.in/in-focus-article.htm?23225/New+Election+tools+in + New+Age+India.

5. Jigeesh, AM (2019), 'Why old-world political campaigning a dying art', The Hindu. Retrieved from https://www.thehindubusinessline.com/news/why-old-world-political-c ampaigning-is-a-dying-art/article26105485.ece.

6. Pathak, Shikha and Raj Kishore Patra (2015), "Evolution of Political Campaign in India" International Journal of Research and Scientific Innovation, Volume II, Issue VIII.

7. Social Media brings paradigm shift to governance in India, The $\begin{array}{llrr}\text { Economic Times, } & \text { June }\end{array}$ https://economictimes.indiatimes.com/news/politics-and-nation/socialmedia-brings-paradigm-shift-to-governance-in-india/articleshow/6971 0099.cms?from $=$ mdr.

8. CSDS Report on Social Media and Political Behaviour (2019) Published by Lokniti (CSDS). 
9. K. Rahul (2016), "Use of New Media in Indian Political Campaigning System", Journal of Political Sciences \& Public Affairs.

10. K. Rahul (2016), "Use of New Media in Indian Political Campaigning System", Journal of Political Sciences \& Public Affairs

11. The Economic Times (2019), "Social media plays key role in influencing first-time voters: Report", New Delhi.

\section{AUTHORS PROFILE}

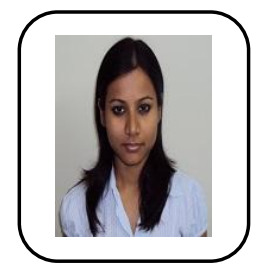

Jayasree Nath is a Doctorate in Internationa Relations from Jawaharlal Nehru University, New Delhi. Presently she is working as assistant professor in NEF College, Guwahati in the department of Political Science. She also holds her M.Phil and Master degree in Political Science from JNU, New Delhi. She wrote 4 articles in ISBN/ISSN and SCOPUS listed journals and contributed chapters in two ISBN books. In addition, to academic profile she worked in 'Institute of Peace and Conflict Studies', New Delhi and 'Center for Land and Warfare studies', New Delhi. 